\title{
Plant growth-promoting rhizobacteria and their potential as bioinoculants on Pennisetum clandestinum (Poaceae)
}

\author{
Felipe Romero-Perdomo ${ }^{1}$, Jhonnatan Ocampo-Gallego ${ }^{2}$, Mauricio Camelo-Rusinque ${ }^{1}$,
} $\&$ Ruth Bonilla ${ }^{1 *}$

1. AGROSAVIA - Corporación Colombiana de Investigación Agropecuaria. Centro de Investigación Tibaitatá. Km. 14 Vía Mosquera, Bogotá D.C, Cundinamarca, Colombia; fromerop@agrosavia.co,mcamelo@agrosavia.co, rbonilla@agrosavia.co

2. Universidad Colegio Mayor de Cundinamarca, Calle 28 \#5B-02, Bogotá D.C, Cundinamarca, Colombia; jsocampog@hotmail.com

* Correspondence

Received 17-VII-2018. Corrected 14-V-2019. Accepted 04-VII-2019.

\begin{abstract}
Introduction: The sustainable production of pastures has become a fundamental challenge for the livestock sector where research with plant growth-promoting rhizobacteria as a viable solution, has nearly not been reported. Objective: In this study, we aimed to examine the potential to stimulate growth in Pennisetum clandestinum grass using four isolated bacterial strains from soils obtained from a Colombian tropical silvopastoral system. Methods: We previously identified genetically the strains and characterized two plant growth promoting activities. In addition, we evaluated the growth-promoting effect of the strains in Kikuyo grass under greenhouse conditions. Results: We found that the four bacterial strains were phylogenetically associated with Klebsiella sp. (strains 28P and 35P), Beijerinka sp. (37L) and Achromobacter xylosoxidans (E37), based on partial 16S rRNA gene sequencing. Moreover, the in vitro biochemical assays demonstrated that the strains exhibited some plant growth promoting mechanisms such as 1-aminocyclopropane-1-carboxylic acid deaminase activity and indole compound synthesis. Notably, bacterial inoculation under greenhouse conditions showed a positive influence on $P$. clandestinum growth. We found a significant $(\mathrm{P}<0.05)$ effect on root and shoot length and shoot dry weight. Shoot length increased by $52 \%$ and $30 \%$ with $37 \mathrm{~L}$ and $35 \mathrm{P}$ compared to those without inoculation treatment. Similarly, the use of $37 \mathrm{~L}$ and $28 \mathrm{P}$ raised shoot dry weight values by $170 \%$ and $131 \%$, respectively. In root development, inoculation with strains 37L and E37 increased root length by $134 \%$ and $100 \%$, respectively. Conclusion: Beijerinckia sp. 37L was the most effective of the four strains at increasing $P$. clandestinum biomass and length.
\end{abstract}

Key words: ACC deaminase; Beijerinckia sp.; indole; Kikuyu grass; PGPR; rhizosphere.

Romero-Perdomo, F., Ocampo-Gallego, J., Camelo-Rusinque, M., \& Bonilla, R. (2019). Plant growth promoting rhizobacteria and their potential as bioinoculants on Pennisetum clandestinum (Poaceae). Revista de Biología Tropical, 67(4), 825-832.

Based on the experimental results obtained by Kloepper and Schroth (1978) on radishes, the term plant growth-promoting rhizobacteria (PGPR) refers to the beneficial soil bacteria that colonize plant roots and confer beneficial effects, such as increased plant growth and decreased susceptibility to diseases. The potential of PGPR in agriculture has been significant during the last ten years as they offer an ecofriendly way to reduce the use of fertilizers, pesticides, and other chemical supplements (Bhattacharyya \& Jha, 2012). Some publications have suggested that PGPR strains operate through a wide variety of metabolic 
mechanisms such as synthesis of 1-aminocyclopropane-1-carboxylate (ACC) deaminase, nitrogen fixation, nutrient solubilization and mineralization (e.g. P, K, Zn), production of plant growth regulators (e.g. indoles, cytokinins and gibberellic acid), and exhibition of antagonistic activity against phytopathogenic microorganisms by siderophores and antibiotics (Timmusk, Behers, Muthoni, Muraya, \& Aronsson, 2017). Recently, numerous studies have shown positive effects on growth, nutritional value, and productivity parameters on fruits, cereals, and vegetables using PGPR inoculation (Pii et al., 2015; Bhardwaj, Ansari, Sahoo, \& Tuteja, 2014). However, most of these reports have been developed under fully controlled in vitro conditions that do not demonstrate whether beneficial bacterial effects also occurs under greenhouse or field conditions (Bashan, Alexander, \& de-Bashan, 2013).

Although there are many studies on plant growth promotion carried out using bacteria on various crops, there is still limited information about the effects of PGPR on the Kikuyu grass growth (Pennisetum clandestinum Hochst. ex Chiov). P. clandestinum is the most widely cultivated grass in Colombia, and it is used as a forage food source for livestock in intensive dual purpose milk and meat production systems (Mejía-Taborda, Ochoa-Ochoa, \& Medina-Sierra, 2014). One of the departments with the highest production of $P$. clandestinum is César, where its economy depends mainly on livestock farming. This grass has nutritional and physiological characteristics that milk and meat producers search for, such as moderate tolerance to water stress, elevated levels of protein, good palatability, and adaptability (Sidari, Panuccio, \& Muscolo, 2004). According to Hungria, Nogueira and Silva-Araujo (2016), several factors affect pasture degradation, including the following: (i) low planting density before grazing is initiated, (ii) forage species unsuitable for local conditions, and in particular (iii) decrease in soil fertility due to chemical fertilizer overuse. In Colombia, grazing soils are poor in essential nutrients and they have moderate concentrations of exchangeable aluminum; moreover, these also have deficiencies in phosphorus, calcium, and magnesium (Muscolo, Panuccio, \& Eshel, 2013). Therefore, the maintenance of pasture growth becomes a pivotal challenge to the sustainable management of Colombian tropical soils under livestock production. Considering the above mentioned, the overall aim of this study was to characterize in vitro plant growth promotion (PGP) traits of native strains of rhizobacteria from the Colombian high-altitude tropics and to study the beneficial effects of their inoculation on the growth of Kikuyu grass under glasshouse conditions.

\section{MATERIALS \& METHODS}

Microorganisms and culture: Four rhizobacterial strains 28P, 35P, 37L, and E37 isolated from soils of a silvopastoral system composed of Leucaena leucocephala, Eucalyptus tereticornis, and Megathyrsus maximus located in Codazzi, department of Cesar, Colombia, were used. These microorganisms were provided by the Soil Microbiology Laboratory of AGROSAVIA, Colombia. Each bacterium was grown in Luria-Bertani medium (10 g tryptone, $10 \mathrm{~g}$ $\mathrm{NaCl}, 5 \mathrm{~g}$ yeast extract and $17 \mathrm{~g}$ agar in $1 \mathrm{~L}$ of distilled water) at $30{ }^{\circ} \mathrm{C}$ for $24 \mathrm{~h}$. To produce bacterial inoculum strains these were cultivated in Moreno-Bonilla-Rojas (MBR) broth (Moreno, Rojas-Tapias, \& Bonilla, 2011) for $24 \mathrm{~h}$ at $30^{\circ} \mathrm{C}$ and stirred at $120 \mathrm{rpm}$. In all in vitro experiments, the bacterial suspensions used were comprised by cells that were previously washed twice in $0.85 \% \mathrm{w} / \mathrm{v}$ of saline solution. On the contrary, in other plant studies, unwashed bacterial cultures were inoculated into Pennisetum clandestinum stolons.

16S rRNA gene sequencing and data analysis: Strains were identified by amplifying and sequencing the $16 \mathrm{~S}$ rRNA gene. Bacterial DNA was extracted using the DNeasy Blood \& Tissue Kit (Qiagen, Germany) according to the manufacturer's instructions. Genomic DNA extracted was diluted in sterile Milli-Q water before conducting PCR analysis under 
the following conditions: a $25 \mu \mathrm{L}$ PCR mixture contained $1 \times$ Taq DNA polymerase buffer (Invitrogen, USA), $2.5 \mathrm{mM} \mathrm{MgCl}, 0.2 \mathrm{mM}$ of each deoxynucleoside triphosphate, 25 pmol of each forward and reverse primers, $1 \mathrm{U}$ of DNA polymerase (Invitrogen, USA), and 50 ng of genomic DNA as template (Rojas-Tapias et al., 2012). Amplification of 16S-rRNA gene was carried out by PCR with an iCycler thermocycler (BioRad, USA) using the forward primer 27F 5'-AGAGTTTGATCCTGGCTCAG-3' and the reverse primer 1492R 5'-GGTTACCTTGTTACGACTT-3'. The PCR conditions including a pre-heating step for 2 min at $95{ }^{\circ} \mathrm{C}$, denaturation in 35 cycles of $30 \mathrm{sec}$ at $95{ }^{\circ} \mathrm{C}$, annealing for $30 \mathrm{sec}$ at 57 ${ }^{\circ} \mathrm{C}$, elongation for $2 \mathrm{~min}$ at $72{ }^{\circ} \mathrm{C}$ and extension step for $10 \mathrm{~min}$ at $72{ }^{\circ} \mathrm{C}$. PCR products were purified using Wizard ${ }^{\circledR}$ SV Gel and PCR Clean-Up System kit (Promega, USA). Finally, the products were run in the BigDye terminator cycle sequencing kit and the $\mathrm{ABI}$ 310 DNA Sequencer (Applied Biosystems, Foster City, CA). Partial sequences obtained were analyzed using the BLAST algorithm and compared with registered sequences found in the GenBank database of NCBI where they were later deposited.

Synthesis of ACC deaminase and indoleacetic acid: To evaluate whether our microorganisms exhibit two mechanisms related to plant growth promotion, biochemical tests under in vitro conditions were performed. All strains were evaluated for their capacity to metabolize ACC as a nitrogen $(\mathrm{N})$ source for bacterial growth as described by Habib, Kausar and Saud (2016). Three types of minimal salt mediums (MSM) were used: (1) without $\mathrm{N}$ source and replaced with $\mathrm{MgSO}_{4}(0.1 \mathrm{M})$; (2) with $\left(\mathrm{NH}_{4}\right)_{2} \mathrm{SO}_{4}(0.1 \mathrm{M})$; and (3) with ACC $(3 \mathrm{mM})$. The optical density (OD $600 \mathrm{~nm}$ ) was measured in a 96-well plate for $6 \mathrm{~d}$ at $30^{\circ} \mathrm{C}$ and $150 \mathrm{rpm}$. To determine if our strains were able to consume ACC, we statistically compared the OD values of the three broths mentioned above. Additionally, indolic compounds were estimated using the colorimetric assay based on the modified Salkowski reagent (Glickmann \& Dessaux, 1995) and standard tryptic soy broth (TSB) medium supplemented with $100 \mathrm{mM}$ of tryptophan. Cells were incubated for $72 \mathrm{~h}$ at $150 \mathrm{rpm}$. Supernatants were mixed with the Salkowski reagent in a 4:1 ratio for 20 min under dark conditions. Indoleacetic acids (IAA) were spectrophotometrically determined at $535 \mathrm{~nm}$. Each measurement was performed by triplicate.

Plant inoculation experiment: To study plant growth promotion in Pennisetum clandestinum mediated by individual inoculation with 28P, 37L, 35P, and E37 strains, we used a completely randomized design with three replicates under glasshouse conditions at the C.I. Tibaitatá (CIT), AGROSAVIA in Mosquera, Cundinamarca, Colombia. Grass stolons of $P$. clandestinum with a length of $9 \mathrm{~cm}$ were collected and surface-sterilized with $5 \%$ sodium hypochlorite $(10 \mathrm{~min})$, followed by $70 \%$ ethanol (1 min), and finally rinsed three times (5 min) in distilled-sterilized water (Ryu et al., 2003). Two stolons were grown separately in $2 \mathrm{~kg}$ polyethylene pots, each pot filled with soil from the $P$. clandestinum crops at CIT. A distance of $20 \mathrm{~cm}$ was used between each experimental unit (pot). The soil was air-dried at $37^{\circ} \mathrm{C}$ for three days, and then, it was sieved with a $2.0 \mathrm{~mm}$ mesh. Soil characteristics were established by the Soil Chemistry Laboratory of AGROSAVIA. Phosphorous was quantified using the Bray II method, and sulfur was measured by extraction with $\mathrm{Ca}\left(\mathrm{H}_{2} \mathrm{PO}_{4}\right)_{2}$ and turbidimetric quantification with $\mathrm{BaCl}_{2}(\mathrm{pH}$ 6.5 , percentage of organic matter $(11.6 \%)$, effective cation exchange capacity $(3.29 \mathrm{cmol}$ $\left.\mathrm{kg}^{-1}\right)$, exchange capacity $\left(1.13 \mathrm{ds} \mathrm{m}^{-1}\right), \mathrm{P}(4.08$ $\left.\mathrm{mg} \mathrm{kg}^{-1}\right), \mathrm{S}\left(13.25 \mathrm{mg} \mathrm{kg}^{-1}\right), \mathrm{Ca}\left(1.29 \mathrm{mg} \mathrm{kg}^{-1}\right)$, $\mathrm{K}\left(0.77 \mathrm{cmol} \mathrm{kg}^{-1}\right), \mathrm{Na}\left(0.11 \mathrm{cmol} \mathrm{kg}^{-1}\right)$, and $\mathrm{Mg}\left(0.63 \mathrm{cmol} \mathrm{kg}^{-1}\right)$. To inoculate according to treatments, stolons were submerged in the appropriate bacterial inoculum $\left(\mathrm{OD}{ }_{600 \mathrm{~nm}}=\right.$ 0.5 ) for $30 \mathrm{~min}$ and then planted. MBR liquid medium (Moreno et al., 2011) was used as a control. Moreover, $5 \mathrm{~mL}$ of inoculum or MBR broth were applied manually around the 
planted stolon in each pot. Grass stolons were thinned to one plant per pot 15 days after planting. These were cultivated in a glasshouse at $15-25^{\circ} \mathrm{C}$ and at a $16 / 8 \mathrm{~h}$ day/night light regime. After 30 days, shoot and primary root length were recorded. Then, these vegetative tissues were oven-dried separately at $60{ }^{\circ} \mathrm{C}$ for $48 \mathrm{~h}$ to measure their dry weights.

Statistical analysis: Data on different plant parameters measured in the pot experiment were statistically analyzed with an analysis of variance (ANOVA) and using the software package SPSS version 17.0. Treatment means were compared by applying the HSD Tukey test (LSD) at $5 \%$ probability.

\section{RESULTS}

\section{Identification of bacterial strains:} Through 16S rDNA sequence analysis, we found that strain 28P and strain 35P have homology with bacteria belonging to the genus Klebsiella, strain $37 \mathrm{~L}$ with bacteria belonging to the Beijerinckia genus, and strain E37 with the Achromobacter genus. All sequences were submitted to the NCBI/GenBank database (Table 1).

Screening of in vitro PGP activities: We observed that the only bacterium capable of using ACC as a nitrogen source was Beijerinckia sp. strain 37 L. Statistically significant differences (data reported as positive) were found in the OD $600 \mathrm{~nm}$ of strain $37 \mathrm{~L}$ measured in a minimal salt medium (MSM) supplemented with ACC as compared to ammonium sulfate (positive control) and magnesium sulfate (negative control). On the other hand, all four strains were able to produce indoles in tryptic soy broth (TSB) supplemented with tryptophan $(100 \mathrm{mM})$. The maximum concentration of indoles was synthesized by strain 35P, with $339.26 \mu \mathrm{g} \mathrm{mL}^{-1}$ per OD $630 \mathrm{~nm}$ unit (Table 1).

Plant growth promotion assay: Results showed that bacterial inoculation significantly improves $(\mathrm{P}<0.05)$ Kikuyu growth compared to the control (Fig. 1). Average shoot length enhancement was 52, 30, 25, and $20 \%$ compared to the control when $37 \mathrm{~L}, 35 \mathrm{P}, \mathrm{E} 37$, and 28P were applied, respectively. Similarly, increases higher than $100 \%$ were observed in shoot dry weight in inoculated treatments. For example, the use of $37 \mathrm{~L}$ and $28 \mathrm{P}$ stimulated shoot dry weight by 170 and $131 \%$ in comparison to the control. In contrast, root development was significantly influenced in length only. The application of strains $37 \mathrm{~L}$ and E37 increased root length by $134 \%$ and $100 \%$ with values of $53.95 \mathrm{~cm}$ plant $^{-1}$ and $46.16 \mathrm{~cm}$ plant $^{-1}$ compared to $23 \mathrm{~cm}$ plant $^{-1}$ of the control treatment. Furthermore, we observed a positive effect in root dry weight, without statistically significant differences between evaluated treatments. Furthermore, microorganisms $35 \mathrm{P}$ and

TABLE 1

Plant growth promoting traits of the strains assessed

\begin{tabular}{|c|c|c|c|c|c|}
\hline \multirow[b]{2}{*}{ Strain } & \multirow[b]{2}{*}{ Accession number } & \multirow[b]{2}{*}{ Nearest phylogenetic neighbor } & \multirow[b]{2}{*}{ Identity (\%) } & \multicolumn{2}{|r|}{ Synthesis } \\
\hline & & & & $\mathrm{ACCd}$ & $\begin{array}{c}\text { IAA } \\
\left(\mu \mathrm{g} \mathrm{mL}^{-1} \text { per } \mathrm{OD}_{630 \mathrm{~nm}} \text { unit }\right)\end{array}$ \\
\hline $28 \mathrm{P}$ & MG904940 & Klebsiella sp. & 99 & - & $72.64 \pm 9.06$ \\
\hline $37 \mathrm{~L}$ & MG904942 & Beijerinckia sp. & 99 & + & $53.89 \pm 5.52$ \\
\hline $35 \mathrm{P}$ & MG904941 & Klebsiella sp. & 99 & - & $339.26 \pm 12.59$ \\
\hline E37 & MG904943 & Achromobacter xylosoxidans & 99 & - & $5.21 \pm 0.61$ \\
\hline
\end{tabular}

PGP: Plant growth promoting trait; ACCd: aminocyclopropane-1-carboxylate deaminase; IAA: indole-3-acetic acid. Values represent means \pm standard deviation; $(+/-)$ indicates presence/absence of the trait. Each measurement was performed in triplicate. 

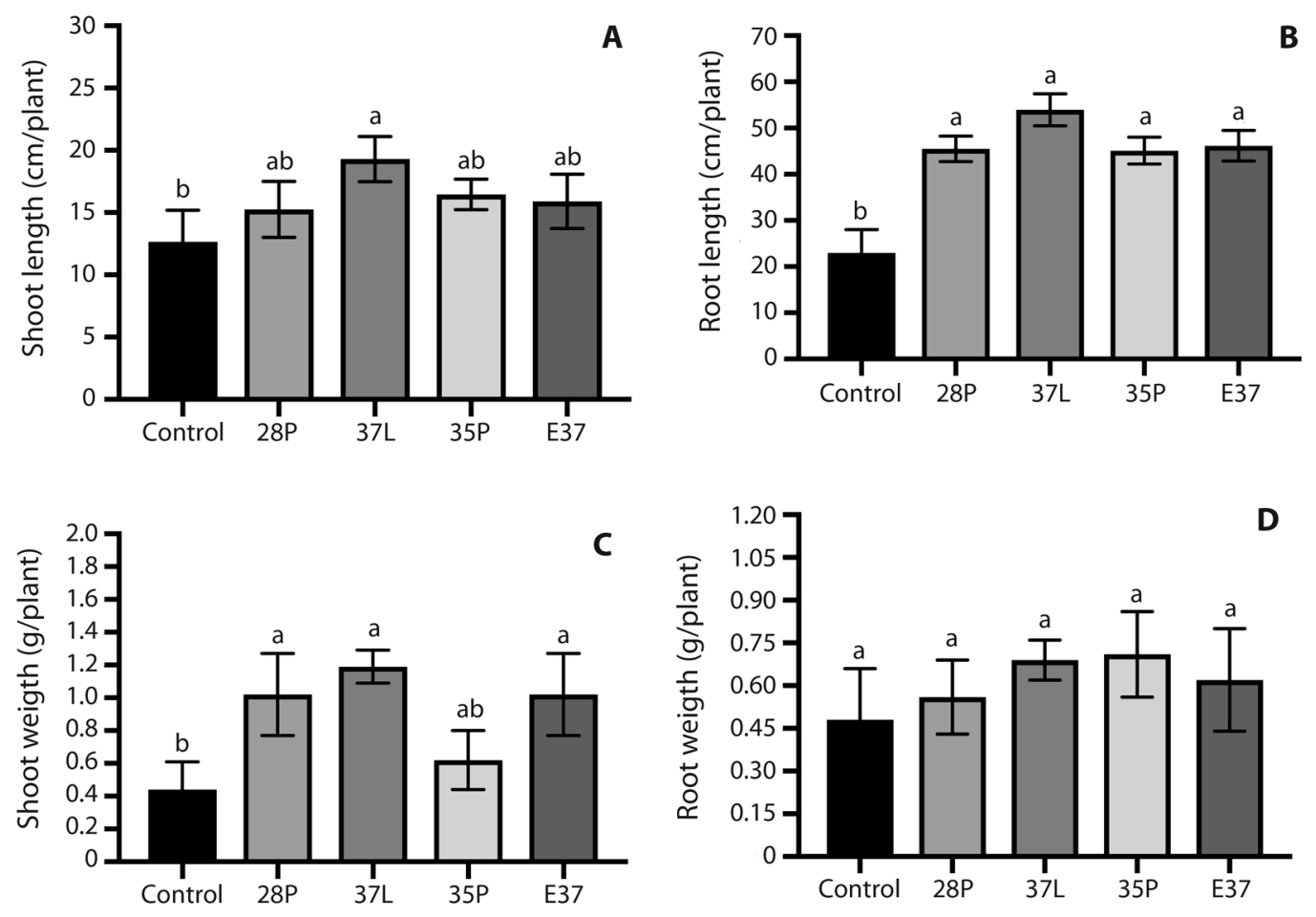

Fig. 1. Effect of inoculation with Klebsiella sp. 28P, Beijerinckia sp. 37L, Klebsiella sp. 35P, and Achromobacter sp. E37 on Pennisetum clandestinum development expressed as: (A) Shoot length, (B) Root length, (C) Shoot weight, and (D) Root weight, under greenhouse conditions. Error bars represent \pm standard deviation. Letters denote significant differences based on the HSD Tukey test.

37L showed 0.714 and 0.69 g plant $^{-1}$, whereas the control only showed 0.48 g plant $^{-1}$.

\section{DISCUSSION}

Based on the positive impact of using PGPR we conducted this study to evaluate the effect of four bacterial strains isolated from a silvopastoral system in the Colombian high elevation tropics on Kikuyu grass growth. Initially, we studied whether our microorganisms exhibited two mechanisms related to plant growth promotion in morphometric variables through biochemical tests under in vitro conditions (Table 1). The first plant growth promoting feature evaluated was the ability of the bacteria to consume 1-aminocyclopropane1-carboxylate (ACC) as a source of nitrogen by the enzyme ACC deaminase. We observed that
Beijerinckia sp. 37L was the only strain that showed significant growth in presence of ACC. The technique used allows the indirect observation of the synthesis of the ACCd enzyme. According to Glick (2014), the main role of the enzyme ACC deaminase is to mitigate the negative effects of biotic and abiotic stresses in plants by preventing deleterious levels of ethylene in plant tissues. Furthermore, other researchers have supported the premise that hydrolysis of ACC improves root elongation (Nascimento, Rossi, Soares, McConkey, \& Glick, 2014).

Production of phytohormone-like compounds such as indole-3-acetic acid (IAA), is a bacterial response to the interaction with the substances produced by the plant in the soil rhizosphere. IAA is involved in the root system and cell development (Sukumar et al., 
2013). All our strains showed a remarkable ability to release IAA from tryptophan as a precursor, ranging from 5.21-339.26 $\mu \mathrm{g} \mathrm{mL}^{-1}$ per $\mathrm{OD}{ }_{630 \mathrm{~nm}}$ unit. Under natural conditions, we find L-tryptophan in organic compounds synthesized by plant roots which can be used by PGPR for IAA bioproduction (Majeed, Kaleem-Abbasi, Hameed, Imran, Rahim, 2015). It is important to note that Beijerinckia sp. $37 \mathrm{~L}$ was able to produce both ACCd and indole compounds, and its inoculation generated the greatest beneficial effect on Kikuyu roots. In this sense, and considering the abovementioned results, we hypothesize that the root system of the Kikuyu grass (biomass and length) is influenced by both mechanisms of the Beijerinckia sp. 37L strain. Overall, our results strongly suggested that the four strains studied exhibit PGP attributes and that their inoculation in crops might beneficially influence plant growth Hence, these microorganisms were subject to plant assays under greenhouse conditions with Kikuyu grass.

The greenhouse experiment allowed us to demonstrate the positive influence of bacterial inoculation on Kikuyu grass growth. Interestingly, we observed a significant effect on root length, shoot length, and shoot dry weight, especially in the case of inoculating with Beijerinckia sp. 37L. The average percentage increases in root length, root dry weight, shoot length, and shoot dry weight in all the evaluated strains were $105,34,37$, and $134 \%$, respectively. Similar observations have been described in the few investigations reported on the use of PGPR for forage pastures. Criollo, Obando, Sánchez and Bonilla (2012) showed that both Stenotrophomona sp. 4K and Pseudomonas sp. 5B improve root dry weight and shoot dry weight in P. clandestinum by $50 \%$, respectively. In addition, other studies in Brazil have demonstrated the effective use of the bacterium Azospirillum brasilense for biological nitrogen fixation in forage grasses, and thus, achieved reduced rates in the use of chemical fertilizers (Hungria, Nogueira, \& Silva-Araujo, 2016; Sudhakar, Chattopadhyay, Gangwar, \& Ghosh, 2000).
Our results were obtained in soils from sites where Kikuyu grass is one the most predominant pastures. This soil did not receive applications of mineral fertilizers or bacterial inoculations for the previous three years. The objective of using these conditions was to observe the plant growth promotion effect from the bacterial inoculation in Kikuyu grass to simulate real conditions to those applied commercially. Moreover, some researchers suggest that it is not enough to perform only laboratory tests under controlled conditions to observe the beneficial effect of PGPR on plants (Collavino, Sansberro, Mroginski, \& Aguilar, 2010). An explanation of the results found might be based on previous reports that infer that the positive effect on plant growth is attributed via one or more growth promoting characteristics of the strains inoculated (Romero-Perdomo et al., 2017; Rojas-Tapias, Bonilla, \& Dussán, 2014). Interestingly, the strain with the greatest growth-promoting effect on $P$. clandestinum grass, Beijerinckia sp. 37L, was the only bacterium that exhibited the two PGP traits evaluated. Extensive studies are needed on the strain Beijerinckia sp. 37L using molecular biology and bioinformatic tools to elucidate the intrinsically associated metabolic mechanism in growth promotion of Kikuyu grass.

In conclusion, the four strains evaluated in this study generate a beneficial effect on the growth of Kikuyu grass, but Beijerinckia sp. strain 37L showed the most significant influence on both the biomass and the length of P. clandestinum. Moreover, the biochemical characterization allowed us to observe that our microorganisms exhibit plant growth promotion properties, which might explain indirectly the results observed in the greenhouse experiments. Field tests are necessary to study the response of Kikuyu grass when inoculated with Beijerinckia sp. strain 37L, measuring bromatological and nutritional parameters.

Ethical statement: authors declare that they all agree with this publication and made significant contributions; that there is no conflict of interest of any kind; and that we 
followed all pertinent ethical and legal procedures and requirements. All financial sources are fully and clearly stated in the acknowledgements section. A signed document has been filed in the journal archives.

\section{ACKNOWLEDGMENTS}

The authors wish to thank Ministerio de Agricultura y Desarrollo Rural (MADR) of Colombia for supporting this research. All the authors are also very grateful to Ines Roldán and Stella Mendieta for their technical assistance, to Mauricio Barón for his support during the greenhouse evaluations, to Lady Molano for carrying out the administrative management, and to Sergio Pardo for helping with the bacterial identification. The authors declare that there are no conflicts of interest.

\section{RESUMEN}

\section{Rizobacterias promotoras del crecimiento de plantas y su potencial como bioinoculantes en Pennisetum clandestinum (Poaceae)}

Introducción: La producción sostenible de pastos se ha convertido en un desafío fundamental para el sector ganadero, donde investigaciones con bacterias promotoras de crecimiento vegetal, como una solución viable, han sido poco reportadas. Objetivo: El objetivo de este estudio fue examinar el potencial para estimular el crecimiento del pasto Pennisetum clandestinum utilizando cuatro cepas bacterianas aisladas de suelos obtenidos de un sistema silvopastoril tropical colombiano. Métodos: Anteriormente identificamos genéticamente las cepas y caracterizamos dos actividades que promueven el crecimiento de las plantas. Además, evaluamos el efecto promotor del crecimiento de las cepas en el pasto Kikuyo en condiciones de invernadero. Resultados: Encontramos que las cuatro cepas bacterianas se asociaron filogenéticamente con Klebsiella sp. (cepas 28P y 35P), Beijerinka sp. (37L) y Achromobacter xylosoxidans (E37), basados en la secuenciación parcial del gen $16 \mathrm{~S}$ rRNA. Además, los ensayos bioquímicos in vitro demostraron que las cepas exhibían algunos mecanismos que promueven el crecimiento de las plantas tales como la actividad de la enzima desaminasa del ácido 1-aminociclopropano-1- carboxílico, y la síntesis del compuesto indol. En particular, la inoculación bacteriana bajo condiciones de invernadero mostró una influencia positiva en el crecimiento de P. clandestinum. Encontramos un efecto significativo $(\mathrm{P}<0.05)$ en la longitud de la raíz y el tallo, y el peso seco del tallo. La longitud del tallo aumentó en un $52 \%$ y $30 \%$ con $37 \mathrm{~L}$ y $35 \mathrm{P}$, respectivamente, en comparación con aquellos sin tratamiento de inoculación. Igualmente, el uso de las cepas 37L y 28P aumentó los valores de peso seco del tallo en un 170 y un $131 \%$, respectivamente. En el desarrollo de la raíz, la inoculación con las cepas 37L y E37 aumentó la longitud de la raíz en 134 y $100 \%$, respectivamente. Conclusión: Beijerinckia sp. 37L fue la más efectiva de las cuatro cepas al aumentar la biomasa y la longitud de $P$. clandestinum.

Palabras clave: ACC deaminasa; Beijerinckia sp.; indol; pasto kikuyo; RPCV; rizósfera.

\section{REFERENCES}

Bashan, Y., Alexander, A. K., \& de-Bashan, L. E. (2013). Tricalcium phosphate is inappropriate as a universal selection factor for isolating and testing phosphatesolubilizing bacteria that enhance plant growth: A proposal for an alternative procedure. Biology and Fertility of Soils, 49(4), 465-79. DOI: https://doi. org/10.1007/s00374-012-0737-7

Bhardwaj, D., Ansari, M. W., Sahoo, R. K., \& Tuteja, N. (2014). Biofertilizers function as key player in sustainable agriculture by improving soil fertility, plant tolerance and crop productivity. Microbial Cell Factories, 13(1), 66. DOI: https://doi. org/10.1186/1475-2859-13-66

Bhattacharyya, P. N., \& Jha, D. K. (2012). Plant growthpromoting rhizobacteria (PGPR): Emergence in agriculture. World Journal of Microbiology and Biotechnology, 28(4), 1327-1350. DOI: https://doi. org/10.1007/s11274-011-0979-9

Collavino, M. M., Sansberro, P. A., Mroginski, L. A., \& Aguilar, O. M. (2010). Comparison of in vitro solubilization activity of diverse phosphate-solubilizing bacteria native to acid soil and their ability to promote Phaseolus vulgaris growth. Biology and Fertility of Soils, 46(7), 727-738. DOI: https://doi.org/10.1007/ s00374-010-0480-x

Criollo, P. J., Obando, M., Sánchez, L., \& Bonilla, R. (2012). Effect of plant growth-promoting rhizobacteria (PGPR) associated to Pennisetum clandestinum in the altiplano cundiboyacense. Revista Corpoica Ciencia y Tecnología Agropecuaria, 13, 189-95.

Glick, B. R. (2014). Bacteria with ACC deaminase can promote plant growth and help to feed the world. Microbiological Research, 169(1), 30-39. DOI: https://doi. org/10.1016/J.MICRES.2013.09.009

Glickmann, E., \& Dessaux, Y. (1995). A critical examination of the specificity of the Salkowski reagent for indolic compounds produced by phytopathogenic bacteria. Applied and Environmental Microbiology, 61(2), 793-96. DOI: http://www.ncbi.nlm.nih.gov/ pubmed/16534942 
Habib, S. H., Kausar, H., \& Saud, H. M. (2016). Plant growth-promoting rhizobacteria enhance salinity stress tolerance in okra through ROS-scavenging enzymes. BioMed Research International, 2016, 1-10. DOI: https://dx.doi.org/10.1155/2016/6284547

Hungria, M., Nogueira, M. A., \& Silva-Araujo, R. (2016). Inoculation of Brachiaria Spp. with the plant growthpromoting bacterium Azospirillum Brasilense: An environment-friendly component in the reclamation of degraded pastures in the tropics. Agriculture, Ecosystems \& Environment, 221, 125-31. DOI: https://doi.org/10.1016/j.agee.2016.01.024

Kloepper, J. W., \& Schroth, M. N. (1978). Plant growthpromoting rhizobacteria on radishes. In Proceedings of the 4th International Conference on Plant Pathogenic Bacteria II, Station de Pathologie Vegetale et Phytobacteriologie, 2, 879-882.

Majeed, A., Kaleem-Abbasi, M., Hameed, S., Imran, A., \& Rahim, N. (2015). Isolation and characterization of plant growth-promoting rhizobacteria from wheat rhizosphere and their effect on plant growth promotion. Frontiers in Microbiology, 6, 1-10. DOI: https:// doi.org/10.3389/fmicb.2015.00198

Mejía-Taborda, A. C., Ochoa-Ochoa, R., \& Medina-Sierra, M. (2014). Efecto de diferentes dosis de fertilizante compuesto en la calidad del pasto kikuyo (Pennisetum clandestinum Hochst. ex Chiov.). Pastos y Forrajes, 37(1), 31-37. DOI: http:/www.redalyc.org/ pdf/2691/269131241004.pdf

Moreno, A. E., Rojas-Tapias, D. F., \& Bonilla, R. (2011). Aplicación de diseños estadisticos secuenciales en la identificacion de fuentes nutricionales para Azotobacter choroococcum AC1. Revista Corpoica Ciencia y Tecnología Agropecuaria, 12, 151-157. DOI: 10.21930/rcta. vol12_num2_art:226

Muscolo, A., Panuccio, M. R., \& Eshel, A. (2013). Ecophysiology of Pennisetum clandestinum: A valuable salt tolerant grass. Environmental and Experimental Botany, 92, 55-63.

Nascimento, F. X., Rossi, M. J., Soares, C. R. F. S., McConkey, B. J., \& Glick, B. R. (2014). New insights into 1-aminocyclopropane-1-carboxylate (ACC) deaminase phylogeny, evolution and ecological significance. PLoS ONE, 9(6), e99168. DOI: https://doi. org/10.1371/journal.pone.0099168

Pii, Y., Mimmo, T., Tomasi, N., Terzano, R., Cesco, S., \& Crecchio, C. (2015). Microbial interactions in the rhizosphere: Beneficial influences of plant growth-promoting rhizobacteria on nutrient acquisition process.
A review. Biology and Fertility of Soils, 51(4), 40315. DOI: https://doi.org/10.1007/s00374-015-0996-1

Rojas-Tapias, D., Moreno-Galván, A., Pardo-Díaz, S., Obando, M., Rivera, D., \& Bonilla, R. (2012). Effect of inoculation with plant growth-promoting bacteria (PGPB) on amelioration of saline stress in maize (Zea mays). Applied Soil Ecology, 61, 264-72. DOI: https://doi.org/10.1016/J.APSOIL.2012.01.006

Rojas-Tapias, D., Bonilla, R., \& Dussán, J. (2014). Effect of inoculation and co-inoculation of Acinetobacter sp. RG30 and Pseudomonas putida GN04 on growth, fitness, and copper accumulation of maize (Zea mays). Water, Air, \& Soil Pollution, 225(12), 2232. DOI: https://doi.org/10.1007/s11270-014-2232-2

Romero-Perdomo, F., Abril, J., Camelo, M., MorenoGalván, A., Pastrana, I., Rojas-Tapias, D., \& Bonilla, R. (2017). Azotobacter chroococcum as a potentially useful bacterial biofertilizer for cotton (Gossypium hirsutum): Effect in reducing $\mathrm{N}$ fertilization. Revista Argentina de Microbiología, 49(4), 377-383. DOI: https://doi.org/10.1016/j.ram.2017.04.006

Ryu, C. M., Farag, M. A., Hu, C. H., Reddy, M. S., Wei, H. X., Paré, P. W., \& Kloepper, J. W. (2003). Bacterial volatiles promote growth in Arabidopsis. Proceedings of the National Academy of Sciences, 100(8), 4927-4932. DOI: https://doi.org/10.1073/ pnas. 0730845100

Sidari, M., Panuccio, M. R., \& Muscolo, A. (2004). Influence of acidity on growth and biochemistry of Pennisetum clandestinum. Biologia Plant, 48(1), 133-36.

Sudhakar, P., Chattopadhyay, G. N., Gangwar, S. K., \& Ghosh, J. K. (2000). Effect of foliar application of Azotobacter, Azospirillum and Beijerinckia on leaf yield and quality of mulberry (Morus alba). Journal of Agricultural Science, 134, 227-34.

Sukumar, P., Legué, V., Vayssiêres, A., Martin, F., Tuskan, G. A., \& Kalluri, U. C. (2013). Involvement of auxin pathways in modulating root architecture during beneficial plant-microorganism interactions. Plant, Cell \& Environment, 36(5), 909-919. DOI: https:// doi.org/10.1111/pce. 12036

Timmusk, S., Behers, L., Muthoni, J., Muraya, A., \& Aronsson, A. C. (2017). Perspectives and challenges of microbial application for crop improvement. Frontiers in Plant Science, 8, 1-10. DOI: https://doi. org/10.3389/fpls.2017.00049 